\title{
A Call for Radical Imagining: Exploring Anti- Blackness in the Music Therapy Profession
}

\author{
Marisol S. Norris ${ }^{1 *}$ \\ 1 Drexel University, United States \\ *marisol.s.norris@gmail.com \\ Received: 6 October 2020 Accepted: 12 October 2020 Published: 1 November 2020 \\ Editor: Susan J Hadley Reviewer: Brian Abrams
}

\begin{abstract}
This spotlight presentation explores the relationship between anti-Black violence and music therapy. Centering the recent deaths of Ahmaud Arbery, Breonna Taylor, Sean Reed, George Floyd, and Tony McDade, the speaker discusses protests taking place in the United States and throughout the world that demand justice for Black lives. In this presentation, the speaker discusses the interconnectedness of physical and social death as a continuum of oppression the field must contend with to meet social justice aims. Music therapy across the globe is situated within complex sociopolitical, socio-structural, socio-historical, and socio-cultural systems. It holds the vestiges of White European settler colonialism and is founded upon dominant cultural values and ideals that support its existence and simultaneously benefit and harm client communities. While, as a professional body, we aim to deepen music therapy access and conceptualize empowerment from a social justice frame, we must explore the various ways music therapy leverages proximations of power. Any calls for access and empowerment in music therapy amplify our existence within unjust systems and our participation in their perpetuation in education, theory, research, practice, and praxis. The speaker explores anti-Blackness from a Black feminist lens and discusses the radical repositioning of music therapy as we collectively strive to meet social justice aims.
\end{abstract}

Keywords: Black feminist theory, anti-Blackness, Radical Imagining, Black communities

This presentation was originally presented at the World Federation of Music Therapy's 2020 World Congress Spotlight Sessions on Access and Empowerment.

https://drive.google.com/file/d/1xtpRH7M27pilSYTX60xz8had-olir-tw/view

Hmm, hmm, hmm, oh my Lord

$\mathrm{Hmm}, \mathrm{hmm}$, mourner's got a home at last

Hmm, hmm, hmm, oh my Lord

Hmm, hmm, mourner's got a home at last

Mourner, mourner, ain't you tired a-mourning 
Fall down on your knees and join the band with the angels

No harm, no harm, no harm, tell brother Elijah no harm, no harm

Poor mourner's got a home at last

Hmm, hmm, hmm, oh my Lord

Hmm, hmm, mourner's got a home at last

Hmm, hmm, hmm, oh my Lord

Hmm, hmm, mourner's got a home at last

Poor Mourner's Got a Home at Last, is an African American Spiritual. It was constructed and passed down through oral tradition that preserves not only its musical construction but also the embodied legacy of Black personhood in all its complexity. A lament, it signifies the pain, struggles, hope, and despair of enslaved peoples of the African Diaspora who, in the face of unyielding brutality and degradation, found death an act of resistance and welcomed relief. As in the middle passage, when enslaved Africans chose to jump overboard slave ships preferring rebellion and death over chattel slavery. This song exemplifies the complex relationship between physical death and what Orlando Patterson (1982) coined as the social death of Black enslaved people whose humanity was pawned as political economy and profiteered by white oppressors. It's with this concept I open today's discussion.

For some joining this spotlight session, you may question the desire to embark on a conversation of death when charged to speak of access and empowerment in music therapy. After all, what does the potentially solemn discussion of death offer social justice? The realities of the COVID-19 pandemic, having a global impact, have amplified the numerous social and economic inequities and systemic health disparities experienced by disenfranchised peoples at the margins of our societies. We could certainly find a range of possible topics that would speak to the life-affirming potential of the music therapy profession and support a music therapy agenda that promotes the current work to meet the global needs of equity and justice. However, while at this time all peoples have undoubtedly considered the extensional crisis of life and death, the paradox of the vast devaluation of Black life to the point of torture and execution lays at the center of my being. At a time when our communities are tasked to meet the demand for the preservation of life, the necessity of breath, the calls of justice for George Floyd's last breath ripple throughout protest-filled streets. And while I sit here in my family's home in Kissimmee, Florida, I am effortlessly reminded of the interconnectedness of both life and death, hope and disillusionment, and the aspiration of social justice most conversations of empowerment and access must contend. Physical death.

I often grapple with this idea of death, recognizing the multiple ways music therapy is linked to the social death of Black people. Ta-Nehisi Coates (2015) states:

But all our phrasing-race relations, racial chasm, racial justice, racial profiling, white privilege, even white supremacy - serves to obscure that racism is a visceral experience, that it dislodges brains, blocks airways, rips muscle, extracts organs, cracks bones, breaks teeth. You must never look away from this. You must always remember that the sociology, the history, the economics, the graphs, the charts, the regressions all land, with great violence, upon the body. (p. 10)

Reflecting on my experience as a music therapy student, I keenly remember the case study of Johnny. Johnny was a 41-year-old male whose stay on the short-term psychiatric inpatient unit was nearing its end. Johnny's case summary detailed diagnostic features, health service encounters, non-adherence to medical treatment, history of drug use, and upbringing in a city district. Prior to entering the hospital, Johnny's aunt, with whom he lived, died, and Johnny was left without his primary support. As my class members and I witnessed video footage of the initial music therapy assessment, we discussed Johnny's diagnostic features. Despite the presence of a depressed mood and possible response to internal stimuli, Johnny played the xylophone with a level of familiarity. His musical interaction featured sweeping melodic lines supported by the jazz chordal accompaniment of the music therapist. As a class, we discussed the self- 
direction of his musical responsiveness that was couched within a discussion of potential schizoaffective symptomatology. We discussed the importance of strength-based assessment and Johnny's evidenced health that may not have been witnessed if not for the presence of music. And while a rousingly complex discussion of musically engaged health ensued, the classroom discussion of Johnny's musical presentation was paired with a static and unidimensional preoccupation with Johnny's potential therapeutic compliance and overall "cool" musical demeanor. As we peered into Johnny's world, we discussed endless aspects of his case. All the while, his existence as a Black male within politicized systems of music and health were minimally explored, and racial determinants of his experience remained unnamed and unacknowledged, thusly rendered invisible.

At the risk of centering whiteness to the point of our own erasure, I, like many Black music therapists and students tasked to theorize and integrate disparate knowledge from varying disciplines, have cried from the hinterlands in need of places that affirm our Black subjectivity, Black representations, Black aesthetic experiences, and their meanings within music therapy contexts. The intentional and unintentional suppression of Black narratives, Black aesthetic discourse, and their theoretical contributions to our profession, index a greater alignment to and perpetuation of color-evasiveness, an unacknowledged existence- $a$ third-worldness within music therapy. This is detailed by Cliff Joseph (1974) in Art Therapy and the Third World and is largely apparent to many Black therapists between the lines of music therapy discourse. These enactments index the developmental progression of predominantly white disciplinary institutions that contend racial visibility and a music therapy field as a space that until recently had minimally considered the politicalized nature of its work. The continued contending of Black therapists, students, and clients alike with socioeconomic and political matrixes of power inherent not only within the more expansive ecological systems of our societies but also within music therapy systems represents points of resilience and the common displacement of Black narratives and our inherent struggle to survive. Consequently, the psychological wounds inflicted upon Black music therapy participants are relegated invisible because their lived realities continue to be unnamed and unacknowledged, while white supremacy in music therapy aims to perpetuate our devaluation and assault our sense of self. Social death.

I record this speech in June 2020, during the second week of U.S. protests that demand justice for George Floyd and Black Lives. As the solidarity of protesters and the multigenerational work and strategic planning of community activism are made evident in grassroots organizing, social media streams, and news outlets, I am reminded that death has always been the other side of power and access. The cries from the streets-“I can't breathe"-reiterate George Floyd's last words as he gasped for air choked from his body beneath U.S. police officer Derek Chauvin's pinned knee for almost nine consecutive minutes. These cries amplify the radical resistance that would relentlessly work for the freedoms of all peoples and the brutal injustice that would attempt to measure the worth of Black lives. George Floyd's lifeless body made public display is invariably tethered to the last words of Eric Garner, another Black cisman, who too was asphyxiated through excessive force by U.S. police. Both laid cold on a city street, tethered to a countless number of Black people whose lives and deaths are a part of the history of police brutality, anti-Black violence, and white supremacy. Protests echo justice for Breonna Taylor, a 26-year-old cis-woman who was shot eight times and killed by U.S. police while she lay sleeping in her bed on March 13. They echo justice's call for Tony McDade, a black trans-man in Tallahassee, Florida who, on May 27, was fatally shot by police with details yet unknown. For Sean Reed, 21 years old, shot in the back while lying on the ground before the police on May 6. For Steven Demarco Taylor. Manuel Ellis. Ahmaud Arbery. Ariane McCree. Atatiana Jefferson. Pamela Turner. Miles Hall. Botham Jean. Stephon Clark. Jordan Edwards. Korryn Gaines. Sandra Bland. Kalief Browder. Yvette Smith. Freddie Gray. Walter Scott. Megan Hockaday. Tamir Rice. Tanisha Anderson. Aura Rosser. Michelle Cusseaux. Mike Brown. Renisha McBride. Jonathan Ferrell. Trayvon Martin. Amadou 
Diallo. James Byrd, Jr. Emmett Till. Mary Turner. And the many more Black peoples whose lives necessitated the urgent cry of All. Black. Lives. Matter.

As the demands for Black lives reverberate throughout U.S. streets, I would be remiss to think that these fights for justice exist in isolation. Calls for George Floyd and for racial equity and police reform and defunding echo from Pretoria, Kingston, Rio de Janeiro, Madrid, Edinburgh, Manchester, London, Brussels, Frankfort, Tunis, New Delhi, Seoul, Hong Kong, Tokyo, Sydney, and from Palestine. They amplify the rising articulation of demands and actions by social and political movements across the globe and the interconnectedness of these struggles. This solidarity speaks to the anti-Blackness that permeates much of our globe, as well as the unyielding violence against humanity that necessitates centering the apartheid conditions of Palestine, the xenophobic violence towards Nigerians in South Africa, the civil rights violations in Hong Kong, war crimes in Syria, and the neo-colonial regimes that continue to oppress the Aboriginal and Torres Strait Islanders in the land called Australia. They center food apartheid, forced sterilization, tuberculosis, non-communicable diseases in low-resourced communities, racial trauma, and a wide host of health injustices linked to medical apartheid. They collectively signify the physical and metaphorical knees placed on the necks of oppressed peoples and the demand of protesters, so-called rebel dreamers, who would combine the urgency of radical imagining with the call of unrelenting action for freedom, even unto death. At this moment, just as I have named names of the black peoples who have been murdered by systems of anti-black oppression, I invite you to reflect on the many oppressed from your communities that have experienced death at the knees of systemic injustice.

Music therapy across the globe is situated within a complex sociopolitical context. Although often narrated as a small but growing profession, even marginalized in comparison to traditional healthcare approaches, music therapy holds the vestiges of White European settler colonialism and is founded upon prevailing cultural values and ideals that support its existence, and that simultaneously benefit and harm client communities. As the field attempts to increase professional legitimacy within research and reimbursement-driven healthcare systems, practice based on empirical data has become a growing priority, and of lesser concern are the peoples at the margins that have been decentered in our collective work. The dominant cultural narratives that permeate our general assumptions of music, health, personhood, relationship, community, and culture serve to 1) expand territorial and ideological empires; 2) uphold structural and institutional dominance over indigenous or marginalized worldviews and music and health practices; and 3) uphold and reinforce oppressive healthcare systems (A. Crooke, personal communication, May 28, 2020). Furthermore, in many ways, music therapy superimposes a subordinate nature of minoritized therapists within education, clinical, therapeutic, and research practice. Marginalized music therapists, like me, often navigate a barren disciplinary landscape with little to no scholarly distinction of the socio-political, socio-cultural, and socio-structural realities that mark both our own and our clients' existence. While dominant groups comparatively draw from the same culturally narrow literary canon that too often takes an etic, one-size-fits-all, approach to cultural realities, the potential risk for therapeutic harm to minority clients steadily increases in the lack of culturally relevant theoretical frameworks, community-engaged models, and community-centered research. Marginalized music therapists often seek and cherish marginalized music therapists, author-activists, and community leaders of our field, whose voices have been suppressed and who have worked to gather and create new embodied, intellectual, community-oriented spaces as a professional and personal necessity.

Access and empowerment in music therapy have often been linked to a proximation of power that would leverage music therapy's potential. In this, we find the fundamental flaw with our stagnant efforts towards empowerment and access-they are predicated on the unjust system that would substantiate their existence. Any calls for justice from music therapy amplify our position within unjust systems at best. At worst, they amplify our attempt to hide these realities that perpetuate injustice from within, and 
contend our unanimous desire to help-to do good. However, seldomly is there a call for the tearing down of unjust systems-seldom is there a call for tearing down the master's house (Lorde, 1984).

If the systems were just, our work wouldn't need to center efforts of diversity, equity, or inclusion that, at best, produce strategic action and, at worst, propagate sincere ignorance. If our systems were just, there wouldn't need to be minority student and therapist uprisings that center their calls for justice, their concerns for minority clients, their musicking, their positionality, their ideologies, their values, their ways of being. If the systems were just, there wouldn't be a need to define and redefine empowerment so that the traditional hierarchical nature of therapy that prop-up the individualistic concern for mastery and control, reflected in the hetero-patriarchal imbalance of power in societies, may be addressed. We could tolerate clients' ability to exercise power autonomously as a political subject, rather than support therapeutic approaches that overwhelmingly endorse therapists empowering the client vs. the client holding personal agency in which they empower themselves or are empowered by their communities.

Music therapy needs multi-people movements committed to dismantling what bell hooks (2012) describes as "imperialist white-supremacist capitalist patriarchy" (p. 4). We need to address the "oppressive regimes of racism, heteropatriarchy, empire, and class exploitation that is at the root of inequality, precarity, materialism, and violence in many forms," as stated by Robin Kelley (2016, para. 19). We need movements that consider culturally sustaining practice and explore oppression for a non-linear, multidimensional praxis of interrogation. Just as the brutal murders of Black people named at the beginning of this talk amplify the intersecting oppressions and violence against trans-folx, cis-women, disabled persons, people deemed mentally ill, people who were low-resourced and disenfranchised, and have existed at the margins of our U.S. society, we need to index the intersectionality of oppression that is clearly articulated by Kimberlé Williams Crenshaw (1989) and described by Pumla Dineo Gqola, Chimamanda Ngozi Adichie, Chandra Talpade Mohanty. We must pay our condition unwavering, focused attention.

bell hooks (1994), in Teaching to Transgress, shares that "Theory is not inherently healing, liberatory, or revolutionary. It fulfills this function only when we ask that it do so and direct our theorizing towards this end" (p. 61). To this end, I'm compelled to ask: When we sing, who do we sing for? And for the growing dominant mass that would declare allyship, I ask: Must we sing for you too? To address the issues of social justice, all music therapists must ask: In what ways does our work disenfranchise? In what ways do our lines of cultural transmission cross the lines of appropriation? In what ways do we mirror theft that would cause harm to the indigenous communities we would aim to serve? In what ways do we perpetuate harm? In what ways are our clients helped in spite of our limited recognition of harm, our willful ignorance, our overt and covert denial of our own complicity in the real physical and social death that exists at all ends of this earth? In what ways must the inherently toxic conceptualizations of music therapy have to die so that life can be affirmed? What if we could radically reimagine new possibilities of music therapy that would recourse our trajectory.

Recently, as my sister, Monique, and I prepared for a protest to demand justice for Black lives, she stated, "I can't sing if I can't breathe." While many would render this statement nothing short of an unfathomable act, I was drawn to yet another paradox of Black people across the African diaspora who have done the impossible. For centuries, Black people have voiced pain, struggle, joy, resistance, and liberation through song amidst bondage, enslavement, and violence, even unto death. Still, now George Floyd's legacy is required to sing on through protesters, activists, and allies while the fight for justice for Black lives continues. In so doing, we've dually demonstrated how our expression has been linked to our humanity that allows the creative reimaging of freedom. Yet Monique's words contend any proposed singularity of condition; rather, they amplify the interconnectedness of physical death and social death on a continuum 
of oppression that has demanded Black people to sing or die, and the radical pursuit of freedom that would allow for her to resist any unfathomable impossibility.

Exhalation. Breath. Breathe. Inspiration. Life.

If there were to be a new song, it would be one where the poor moaner seeking home would not resign to the afterlife for justice and freedom-for a home. The poor moaner wouldn't have to moan no more. If something must die, let it be every part of music therapy that serves to threaten the sanctity of freedom of oppressed peoples. Let it be anything that would threaten the radical possibility of self-determination, interdependence, resilience, and resistance. While to even fathom such a radical potential would require a recognition that "the master's tools will never dismantle the master's house," as Audre Lorde (1984, p. 112) so profoundly stated, let death come even to the thought that the music therapy profession can be made whole without those at the margins brought to the center.

And if something must live, let it be true freedom. Let it be the honor we give to all oppressed peoples that couple profound resistance with revolutionary love and hope. Let it be the dynamic freedom movements rising up, growing even in music therapy and the strategic planning that would transform policy, that would transform practice standards, that would transform classrooms, and that would transform our understanding of the profession. Let it be our mothers' determination. Our fathers' dignity. Our families' compassion, resilience, the courage to tell their stories. Our contagious laughter. Let it be our dreams and dreaming. Let it be our ability to be as real as it gets and our courage to live authentic lives. Let it be our multiplicity. Let it be all our possibilities. Let it be Audre Lorde for dismantling not just the master's house but our minds. Let it be Nikki Giovanni's Revolution. Let it be Miriam Makeba. Let it be Nina Simone. Let it be Jamila Woods. Let it be those that have inspired you to actualize radical freedom wherever you are in the world. Let it be a new song.

My question to you is: what must die in music therapy to preserve human dignity? What in music therapy must die so that freedom may be affirmed? And what are our lives worth?

\section{About the author}

Dr. Marisol S. Norris is a board-certified music therapist, critical arts therapist educator, and founder of the Black Music Therapy Network, Inc. Her music therapy clinical and supervisory experience has spanned medical and community health settings and includes work with adult psychiatric and dually diagnosed populations, adolescents facing homelessness, families within the city court system, and medically fragile children. These experiences have profoundly contributed to her critical culturally sustaining lens of music therapy theory and praxis and her dedication to expanding the understanding of Black clients' aesthetic music and health experiences. Her current research focus includes discursive construction of race in music therapy theory and praxis, the role of cultural memory and aesthetics in client and therapist meaning-making processes, pedagogical approaches to culturally sustaining healthcare training and practice, and frameworks for healing justice within Black communities.

Marisol will be joining the College of Nursing and Health Professions' Creative Arts Therapies Department at Drexel University as Director of Music Therapy and Assistant Clinical Professor winter 2021.

\section{References}

Coates, T. (2015). Between the world and me. Spiegel \& Grau.

Crenshaw, K. (1989). Demarginalizing the intersection of race and sex: A Black feminist critique of antidiscrimination doctrine, feminist theory and antiracist politics. University of Chicago Legal Forum, 1989, 139-167.

hooks, b. (1994). Theory as liberatory practice. In Teaching to Transgress (pp. 59-76). Routledge. 
hooks, b. (2012). Writing beyond race: Living theory and practice. Routledge.

Joseph, C. (Ed.). (1974). Art therapy and the third world: A panel discussion presented at the 5th Annual Convention of the American Art Therapy Association [Monograph].

Kelley, R. (2016, November 15). Forum Response: After Trump. Boston Review, http://bostonreview.net/forum/after-trump/robin-d-g-kelley-trump-says-go-back-we-sayfight-back.

Lorde, A. (1984). Sister outsider: Essays and speeches. The Crossing Press.

Patterson, O. (1982). Slavery and social death: A comparative study. Harvard University Press. 